\title{
THE PRINCIPLE OF CONDITIONALITY IN THE CONTEXT OF THE NEW APPROACH TO EU ENLARGEMENT*
}

\author{
Constanța MĂTUȘESCU**
}

\begin{abstract}
The European integration project has evolved enormously over time and, with it, its enlargement policy, enlargement being often presented as one of the European Union's success stories. Although in accordance with the treaties on which it is founded (art. 49 TEU) the Union continues to be defined as a community open to European states, since its extension in 2004 and 2007 to the countries of Central and South-Eastern Europe, the enlargement of the Union is a process that involves a number of conditionalities imposed on candidate countries in terms of the performance they must meet in order to join. The evolutionary nature of these conditionalities, culminating in the Cooperation and Verification Mechanism for post-accession monitoring of Romania and Bulgaria, has been widely emphasized in the doctrine. At the same time, translating the constant tension between deepening and enlarging European integration, an additional requirement has emerged in recent years for the Union itself - that of its capacity to assimilate new members without jeopardizing the political objectives set out in the Treaties, thus strengthening the discretion of the Union and its Member States. A reflection of this orientation in enlargement policy is the fact that, after the 2004 and 2007 enlargements, only Croatia became a member of the Union (in 2013), for a number of other states (mainly in the Western Balkans) the prospect of accession being still quite insecure, despite promises of almost two decades ago. Faced with numerous criticisms that the lack of credible prospects for accession risks derailing reform efforts in the Western Balkans and eroding the Union's influence in the region, on 5 February 2020 the European Commission announced a 'new enlargement methodology', suggesting a new approach to accession negotiations, approved by Member States in March 2020. The paper aims to examine the evolution of enlargement conditionalities in the Commission's new approach and, at the same time, to assess some of the major implications of this new strategy.
\end{abstract}

Keywords: European Union, EU enlargement, new enlargement methodology, conditionality

DOI: 10.53373/ VULS.2021.38.2.002

\section{Introductory aspects. Background}

The issue of conditionality related to the enlargement of the European Union has attracted the attention of a significant number of authors ${ }^{1}$, who have provided comprehensive

\footnotetext{
* A first version of this paper was presented at the 8th CEE LUMEN International Scientific Conference | New Approaches in Social and Humanistic Sciences | LUMEN CEE NASHS 2021 | November 26th, 2021.

** Associate Professor Ph.D., Faculty of Law and Administrative Sciences, „Valahia” University of Targoviste. ${ }^{1}$ See, inter alia,Christophe Hillion, "Enlargement of the European Union: The Discrepancy Between Accession Conditionality and Membership Obligations", in Fordham International Law Journal, Vol. 27, 2004, pp. 715740; Heather Grabbe, The EU's transformative power: Europeanization through conditionality in Central and Eastern Europe, Basingstoke, Palgrave, 2006; Dimitry Kochenov, EU Enlargement and the Failure of Conditionality. Pre-accession Conditionality in the Fields of Democracy and the Rule of Law, Kluwer Law International BV, The Netherlands, 2008; Frank Schimmelfennig, "EU Enlargement and Differentiated Integration: Discrimination or Equal Treatment?", in Journal of European Public Policy, Vol. 21, No. 5, 2014, pp. 681-698; Eli Gateva, European Union Enlargement Conditionality, Palgrave Macmillan, 2016.
} 
analysis of its size and transformative implications (from the perspective of democratization and Europeanization of public policies) for aspiring states, increasingly conditional on the enlargement process in recent rounds, but also on how these conditionalities have had an impact on Member States' obligations within the Union, for example, "paving the way for a more integrated rule of law in the EU"2.

Another aspect emphasized in the doctrine is that there is a growing link between problems within the Union and its position on enlargement, confirming the wide discretion enjoyed by the Member States (it dominated by institutional and national interests, or "the nationalisation of enlargement" "3), which, to a certain extent, challenges the EU's character as an organization open to the participation of all European states.

These findings reflect the fact that the last three rounds of enlargement (2004, 2007 and 2013), which have almost doubled the number of Member States, but also significant economic, political and institutional changes in the Union, have been followed by almost a decade in which the enlargement process with other aspiring states has made little progress.

The succession of crises that the Union went through during this period, but especially the experiences of previous enlargements (regressions even, from the perspective of democratic principles, registered in some states that became members of the EU in the last rounds of enlargement) determined an adjustment of enlargement policy, with implications for its objectivity, clarity and accuracy, raising serious questions about the credibility of EU commitments to aspiring states.

Table 1. Waves of EU enlargement, candidates and potential candidates

\begin{tabular}{|c|c|}
\hline $\begin{array}{l}\text { Successive waves of EU enlargement } \\
\text { - 1. 1973: Denmark, Ireland and the } \\
\text { United Kingdom } \\
\text { - 2. 1981: Greece } \\
\text { - 3. 1986: Portugal and Spain } \\
\text { - 4. 1995: Austria, Finland and } \\
\text { Sweden } \\
\text { - 5. 2004: Czech Republic, Cyprus, } \\
\text { Estonia, Hungary, Latvia, Lithuania, } \\
\text { Malta, Poland, Slovakia and Slovenia } \\
\text { - 6. 2007: Bulgaria and Romania } \\
\text { - 7. 2013: Croatia }\end{array}$ & $\begin{array}{l}\text { Accession negotiations started } \\
\text { - Turkey - October } 2005 \\
\text { - Montenegro - June } 2012 \\
\text { - Serbia - January } 2014 \\
\text { Decisions to open accession negotiations } \\
\text { (2020) } \\
\text { - The Republic of North Macedonia - } \\
\text { candidate country since December } 2005 \\
\text { - Albania - candidate country since June } 2014 \\
\text { Potential candidates } \\
\text { - Bosnia and Herzegovina - application } \\
\text { submitted in February } 2016 \\
\text { - Kosovo - Stabilisation and Association } \\
\text { Agreement entered into force in April } 2016\end{array}$ \\
\hline
\end{tabular}

2 Ivan Damjanovski, Denis Preshova, Is the EU's Accession Conditionality Paving the Way for a More Integrated Rule of Law Policy in the EU?, EU IDEA Op-ed No. 5, March 2020, https://euidea.eu/2020/03/01/is-the-eus-accession-conditionality-paving-the-way-for-a-moreintegrated-rule-of-law-policy-in-the-eu/ (accessed 10 November 2021).

${ }^{3}$ Christophe Hillion, 'The Creeping Nationalisation of the EU Enlargement Policy', Swedish Institute for European Policy Studies, Report 6/2010, https://sieps.se/en/publications/2010/the-creepingnationalisation-of-the-eu-enlargement-policy-20106/Sieps_2010_6.pdf (accessed 10 November 2021) See also Tanja Mayrgündter, The "Enlargement Paradox": Intergovernmental Supranationalism Survives despite the Winds of Change, Les études du CERI, $\mathrm{n}^{\circ} 211$, SciencesPo, 2015; James KerLindsay, loannis Armakolas, Rosa Balfour, Corina Stratulat, The national politics of EU enlargement in the Western Balkans, Southeast European and Black Sea Studies, Vol. 17, No. 4, 2017, pp. 511-522. 
Beyond the major challenges posed by the Covid-19 pandemic, the political context of the last two years, both at the level of the Union and of the countries aspiring to accession, remains quite complicated ${ }^{4}$. On the one hand, the European Union itself is in the process of rethinking its vision of its future (the Conference on the Future of Europe is launched in the spring of this year), but also of the values on which it is based (with a new mechanism for the protection of the rule of law, in force at the beginning of $2021^{5}$ ). On the other hand, while for Turkey, the largest of the countries wishing to join the EU, its ambitions and prospects for accession appear to have faded significantly, in the Western Balkan states it can be seen, in addition to a rather slow pace of reform, a deterioration in the political situation (caused, according to most analysts, by the lost interest of EU capital), a deterioration revealed, among other things, by rising tensions on the Kosovo-Serbia border and the increasingly controversial (more divisive) rhetoric in Bosnia and Herzegovina.

Faced with numerous criticisms that the lack of credible prospects for accession risks derailing reform efforts in the Western Balkans and eroding the Union's influence in the region, the European Union seems to have abandoned the pragmatic approach of enlargement that has taken place in recent years and which has led to a relative freeze on the process. Thus, on 5 February 2020 the European Commission announced a "new enlargement methodology" , suggesting a new approach to accession negotiations. It was approved by Member States in March 20207, in the same month, the European Council approving the opening of accession negotiations with Albania and the Republic of Northern Macedonia ${ }^{8}$; however, European leaders have avoided advancing a deadline for future enlargement (unofficially, it is estimated that this would not be possible until after 2030).

Making a brief review of the main points of the evolution of the conditions related to enlargement, the paper aims to examine the enlargement conditionalities in the Commission's new approach and, at the same time, to assess some of the major implications of this new strategy, emphasizing a possible relationship between the priority given to fundamental political reforms (mainly related to the rule of law and the functioning of democratic institutions) in the enlargement process and concerns about strengthening the internal rule of law mechanism.

\section{EU enlargement. The legal framework of primary law}

The Treaties establishing the European Communities (ECSC, EAEC and EEC Treaties) and the European Union (TEU) are open treaties, the founding members taking into account

\footnotetext{
4 Ionuț-Mircea Marcu, Perspectiva parcursului european pentru statele din Balcanii de Vest. Între „oboseala extinderii”, influențe externe și integrarea europeană, Institutul European din România, Working Paper Series No. 38, Aprilie 2021.

${ }^{5}$ Regulation (EU, Euratom) 2020/2092 of the European Parliament and of the Council of 16 December 2020 on a general regime of conditionality for the protection of the Union budget, OJ L 433I , 22.12.2020, pp. 1-10.

${ }^{6}$ European Commission, Communication from the Commission to the European Parliament, the Council, the European Economic and Social Committee and the Committee of the Regions - Enhancing the accession process - A credible EU perspective for the Western Balkans, COM/2020/57 final.

7 See Council conclusions on enlargement and stabilisation and association process - Albania and the Republic of North Macedonia, 25.03.2020, https://data.consilium.europa.eu/doc/document/ST-70022020-INIT/en/pdf (accessed 20 November 2021).

${ }^{8}$ https://www.consilium.europa.eu/media/43076/26-vc-euco-statement-en.pdf
} 
the possibility of geographical extension by receiving new members (Arts. 98 TECSC, 205 TEAEC and 237 TEEC, respectively, art. O TEU). Thus, according to Article 237 TEEC, "Any European State may apply to become a member of the Community [...]", and according to Article O TEU (Maastricht), "Any European State may apply to become a member of the Union [...]".

With the Amsterdam amendment to the EU Treaty, which renumbered Article O into Article 49 TEU and introduced a reference to Article 6 (1) TEU, Union primary law provides that only European states that respect the values of freedom, democracy, human rights and fundamental freedoms and the rule of law can apply to become members.

The Lisbon Treaty has given up the solemn assertion of the Union's openness and the provisions on accession to and exit from the Union are inserted, according to the classical rules of international treaties, in the final provisions of the TEU, while the rules on the suspension of certain membership rights in the Union are included in the general provisions.

At present, the accession of the new Member States to the European Union is regulated by Article 49 TEU, which states that: "Any European State which respects the values referred to in Article 2 and is committed to promoting them may apply to become a member of the Union. The European Parliament and national Parliaments shall be notified of this application. The applicant State shall address its application to the Council, which shall act unanimously after consulting the Commission and after receiving the consent of the European Parliament, which shall act by a majority of its component members. The conditions of eligibility agreed upon by the European Council shall be taken into account.

The conditions of admission and the adjustments to the Treaties on which the Union is founded, which such admission entails, shall be the subject of an agreement between the Member States and the applicant State. This agreement shall be submitted for ratification by all the contracting States in accordance with their respective constitutional requirements."

According to Article 2 TEU, "The Union is founded on the values of respect for human dignity, freedom, democracy, equality, the rule of law and respect for human rights, including the rights of persons belonging to minorities. These values are common to the Member States in a society in which pluralism, non-discrimination, tolerance, justice, solidarity and equality between women and men prevail".

Despite its rather brief regulation in the text of the treaties, the enlargement of the European Union is a much more complicated process than that which emerges from the text of the only article devoted to it, in the doctrine showing that "it was already clear after the first enlargement round that there were considerable differences between the way the enlargement process was described in the Treaties and the way enlargements were conducted in practice" .

Enlargement law has evolved with each enlargement round, encompassing not only both formal and substantive requirements for admission, but also written and unwritten criteria. The absence of comprehensive guidelines as to what the substantive conditions of Union membership are, has led both the Member States and the EU institutions, in particular the European Council and the Commission, to supplement the Treaty provisions with various requirements. At the same time, as the enlargement process evolved, it became increasingly

${ }^{9}$ Dimitry Kochenov, EU Enlargement and the Failure of Conditionality. Pre-accession Conditionality in the Fields of Democracy and the Rule of Law, Kluwer Law International BV, The Netherlands, 2008, pp. 1314. 
clear that the EU may not be joined as of right and that the question of whether to admit any new Member State lies within the discretion of the Union and its Member States ${ }^{10}$.

The text of the Treaty sets out a number of preconditions for EU membership:

- status as a state (fulfillment of the conditions required by public international law to be considered a subject of international law) - there is the question of a possible candidacy of Kosovo, a state that has unilaterally declared its independence but is not recognized by all Member States;

- "European State" (at least partially located in Europe; the existence of a common European cultural and historical space - combines both the geographical and socio-cultural views of "Europeanism");

- a political condition related to the observance of the values referred to in Art. 2 TEU and the "commitment to promote them".

With regard to the latter precondition, formally, the conditionality on obtaining the status of a member of the democratic character of a state was introduced for the first time by the Treaty of Amsterdam. However, the practice of the EU institutions regarding the enlargement process shows that, from the first round of enlargement, they interpreted the provisions of the enlargement treaties as also implying the political condition related to democracy, the Rule of Law and human rights ${ }^{11}$. Article 49 of the Lisbon Treaty, however, requires more than respect for these values. He calls for a more active commitment to promote them.

\section{The principle of conditionality as a principle of enlargement}

\subsection{Consecration}

The origins of conditionality ${ }^{12}$ are to be found in the process of enlargement to Central and South-Eastern Europe (thus from the fifth round of enlargement) - different from previous extensions both in terms of the number of applicants and in terms of their political environment and considerably different economically. At the same time, the EU itself has become a much more complex structure since the first enlargement.

In essence, the principle of conditionality presupposes the application of certain conditions in the enlargement process, which begins even before the submission of formal applications for membership by the countries; progressing to the next step of the enlargement process, or accession per se, depends on each country's own progress in meeting the necessary conditions at each stage of the accession process.

\footnotetext{
${ }^{10}$ For a more comprehensive analysis, see Christophe Hillion, The Creeping Nationalisation of the EU Enlargement Policy, Swedish Institute for European Policy Studies, Report 6/2010, https://sieps.se/en/publications/2010/the-creeping-nationalisation-of-the-eu-enlargement-policy20106/Sieps_2010_6.pdf (accessed 10 November 2021).

11 Ibidem, p. 33 .

12 In addition to enlargement-related conditionalities, the conditionality system also covers other Union policies, such as economic, cohesion or development policies. See in this regard Peter Berkowitz, Ánge Catalina Rubianes, Jerzy Pienkowski, The European Union's experiences with policy conditionalities, EC-OECD Seminar Series on Designing better economic development policies for regions and cities, 2017, https://www.oecd.org/cfe/regionaldevelopment/Berkowitz_Conditionalities-for-More-EffectivePublic.pdf (accessed 11 November 2021).
} 


\section{a. Accession criteria}

In the process of joining the Union of Central and South-Eastern European states, under increasing pressure for their rapid accession, the European Council meeting in Copenhagen in June 1993 decided that Central and Eastern European countries wishing to do so could become members of the European Union. However, the criteria (known as the "Copenhagen criteria") that candidate countries must meet in order to become EU members have also been set, criteria that had not existed in previous EU enlargements:

- stable institutions guaranteeing democracy, the rule of law, human rights and respect for and protection of minorities;

- a functioning market economy and the capacity to cope with competition and market forces in the EU;

- the ability to take on and implement effectively the obligations of membership, including adherence to the aims of political, economic and monetary union.

The Madrid European Council in December 1995 introduced an additional criterion that of a national administration capable of managing EU membership. The Lisbon Treaty confirms, under the formula "Eligibility criteria approved by the European Council are taken into account", the need to meet both general and additional conditions for a state to be able to join the European Union.

\section{b. Additional conditions}

The conclusions of the Copenhagen European Council revealed an additional requirement which, without being an actual criterion for accession, seems to be confirmed by further developments - the Union's ability to assimilate new members without jeopardizing the political objectives which were established by treaties. Against the background of the constitutional crisis launched in 2005 and the fears related to the effects of the massive enlargement of 2004, which was to continue in 2007 with Romania and Bulgaria, the European Council of December 2006 confirmed the existence of such conditionality. Although it does not refer to the absorption capacity of the Union, but only to the criteria to be met by the Member States, the Treaty of Lisbon contains a number of elements which may lead to the conclusion that a right of accession is not recognized and may be refused accession of a candidate state, even if it meets all the conditions. Thus, on the one hand, the express assertion of the open character of the Union is waived and states are granted only a right to "apply to become a member". On the other hand, the term "accession criteria" set in Copenhagen is replaced by "eligibility criteria", a change which is considered to allow a wider freedom of assessment, emphasizing the intuitu personae character of accession and leaving the European Council the possibility of imposing other conditions. This strengthens the discretion of the Union and its Member States, and the fulfillment of the eligibility criteria does not guarantee admission to the Union. It is necessary to "obtain the support of the bodies involved in the procedure, which must be convinced not only of the fulfillment of the eligibility criteria but, in addition and above all, that integration does not risk endangering their existence"13.

${ }^{13}$ Alexis Vahlas, "Appartenance a l'Union européenne", in Vlad Constantinesco \& al. (dir.), Le Traité établissant une Constitution pour l'Europe. Analyses et commentaires, Strasbourg, Presses universitaires de Strasbourg, 2005, pp. 239-278. 
In addition, at the 1994 Essen European Council, the condition of good neighborly relations was added to the requirements that partner countries must meet in order to be eligible for membership.

\subsection{Application in the context of enlargement to Central and Eastern Europe}

As one author points out ${ }^{14}$, “[s]ince Copenhagen, enlargement has thus become a policy (as opposed to merely a procedure) governed by a set of elaborated substantive rules, encompassing evolving accession conditions and principles. Through this policy, the EU has actively engaged in the preparation of the candidates with a view to transforming them into Member States."

Enlargement based on conditionality consists of three key elements, including (1) conditions set out by the EU with which the country aspiring to membership needs to comply; (2) an incentive structure, which examines the reward-threat balance; and (3) monitoring ${ }^{15}$. Analyzing the enlargement process to Central and Eastern Europe, Gateva highlighted three trends that characterize this process:

- a gradual expansion and specification of EU conditions in the pre-negotiation stage and the negotiation stage (by introducing the 'road-map' a new instrument for opening and closing 29 acquis chapters), while the accession stage was marked with a shift towards differentiated and targeted conditionality (by introducing country-specific conditions with a list of benchmarks);

- transformations in the incentive structure during the EU accession process - a shift from positive conditionality (in terms of accession advancement and financial rewards) in the early accession stages towards negative conditionality in the accession and post-accession stages (preventive sanctions in the form of the internal market and justice and home affairs safeguard clauses to the Accession Treaty);

- the growing relevance of monitoring reports, not only as instruments for the evaluation of the progress achieved but also as the instruments for political pressure.

Thus, the evolving nature of enlargement conditionality culminated in the postaccession stage by the establishment of the Cooperation and Verification Mechanism (CVM) for monitoring Bulgaria's and Romania's progress in several areas after their accession ${ }^{16}$.

\subsection{Applying conditionality in the context of subsequent accession processes}

a. Confirmation of the evolutionary nature of conditionality

Many countries still aspire to join the Union. Given that with regard to Turkey, the most prominent of these, which since 1987 has applied for accession to what was then the European Economic Community and was declared eligible for EU membership in 1999, accession negotiations started in 2005 are blocked until Turkey agrees to apply the Additional Protocol to the Ankara-Cyprus Association Agreement in Cyprus, the focus is on the six Western Balkan states - Albania, Bosnia and Herzegovina, Kosovo, North Macedonia,

${ }^{14}$ Christophe Hillion, The Creeping Nationalisation...., p. 14.

${ }^{15}$ Eli Gateva, European Union Enlargement Conditionality, Palgrave Macmillan, Basingstoke and New York, 2016, p. 28.

${ }^{16}$ See also Constanța Mătușescu, "Câteva considerații privind parcursul României în Uniunea Europeană la peste un deceniu de la aderare", în lon M. Anghel (coord.), De la infăptuirea Marii Unirii la integrarea României în Uniunea European”, Universul Juridic Publishing House, Bucharest, 2019, pp. 64-79. 
Montenegro and Serbia. In June 2003, the EU-Western Balkans Summit in Thessaloniki opened up the prospect of EU membership for these countries, a commitment repeatedly reiterated on several occasions.

The evolution of the accession negotiations with the states of the Western Balkans imposed the preeminence of the political criterion, which became a preliminary criterion for the opening of the accession negotiations, verifying at the same time the implications of each possible accession on the internal cohesion of the Union. Building on lessons learned from previous enlargements and reflecting the evolution of EU policies, the path to accession is now more rigorous and comprehensive than in the past.

As an illustration of the evolutionary nature of the principle of conditionality, starting with the Commission's 2006 Enlargement Strategy ${ }^{17}$ a detailed framework complementing the text of the Copenhagen criteria was developed, composed of different types of legal and political instruments of pre-accession, reform promotion and progress analysis:

- the stabilisation and association process (SAP), established with the aim of eventual EU membership - care include additional conditions for membership, mostly relating to regional cooperation and good neighbourly relations;

- stabilization and association agreements (with each state), as the basis for implementation of the accession process - inter alia, to support the efforts of the respective country to strengthen democracy and the rule of law; they contain a suspension clause in the event of a breach of the provisions of the Treaty on fundamental rights, which also includes respect for the rule of law as one of the 'essential elements' of the respective agreements;

- Instrument for Pre-accession Assistance - IPA II (e.g,11.7 billion Euros for the period 2014-2020) to support the enlargement countries;

- an updated EU enlargement strategy (after 2012) ${ }^{18}$ and a strategy for the Western Balkans (2018) $)^{19}$ which refer to a new approach to enlargement, in which "the accession process is rigorous, built on strict but fair conditionality, established criteria and the principle of own merit". The emphasis is on the principle of 'fundamentals first' in the accession process (with regard to rule of law reform, the Commission highlights three key areas: judicial reforms, tackling organised crime and fighting corruption), by making it a priority in the enlargement process. The Commission's assessment in the country reports has been introduced, focusing on the rule of law as one of the fundamentals. However, the lack of clear indicators set by the EU on the basis of which to monitor and measure the progress of aspiring states in terms of criteria related to the rule of law has led to a lack of predictability regarding expected reforms and has affected the credibility of enlargement process.

$b$. The strong dependence of the evolution of the enlargement process on the will of the Member States and the emphasis on the absorption capacity of the Union, with the consequence of the lack of predictability for the states wishing to accede (the old principle is still applicable, according to which the reforms undertaken lead to EU accession at some point?). The changes involved strengthening Member States' control over policy

${ }^{17}$ Communication from the Commission to the European Parliament and the Council, Enlargement Strategy and Main Challenges 2006 - 2007, COM(2006) 649

${ }^{18}$ Communication from the Commission to the European Parliament and the Council, Enlargement Strategy and Main Challenges 2012-2013, COM (2012) 0600 final.

${ }^{19}$ Communication from the Commission to the European Parliament, the Council, the European Economic and Social Committee and the Committee of the Regions, A credible enlargement perspective for and enhanced EU engagement with the Western Balkans, 6.2.2018. COM(2018) 65 final. 
management, approving benchmarks and assessing their fulfillment by the States meeting within the Council. The acquisition by the Council (and therefore by each of the Member States) of the power to assess the admissibility of an application for membership has led to increasingly politicized decisions and the instrumentalisation of enlargement for domestic political gains. In the case of the Western Balkans, the emphasis on conditions of good neighborly relations and the settlement of bilateral disputes has allowed, for example, Greece (due to a dispute over the country's name) and, more recently, Bulgaria (which raises arguments about language and national identity), to block the opening of accession negotiations with Macedonia, despite the favorable recommendation from the Commission. With regard to the accession negotiations with Turkey, France and Cyprus have imposed a unilateral blockade of some negotiating chapters. Also, the French veto of July $2019^{20}$ resulted in the non-opening of accession negotiations with North Macedonia and Albania in October 2019 (Emmanuel Macron explained his desire to reform the European Union and the enlargement process before further accession negotiations are launched).

As noted in a House of Lords document ${ }^{21}$, "uncertainty about whether progress towards reforms would be met with genuine progress towards accession could give the appearance of the EU making excuses to "close the door", damaging the credibility of the enlargement process".

\section{New enlargement methodology' (2020) - the main innovations}

Faced with widespread criticism that the lack of credible prospects for accession risks derailing reform efforts in the Western Balkans and eroding the Union's influence in the region, on 5 February 2020 the European Commission announced a "new enlargement methodology" to provide a "firm, merit-based prospect of full EU membership for the Western Balkans". Approved by the Member States in March 2020, the new methodology has already been integrated into the existing negotiating frameworks with Montenegro and Serbia and is also included in the draft negotiating frameworks with Albania and Northern Macedonia (their adoption and effective start of negotiations being blocked by the Bulgarian opposition).

In essence, two major innovations of the new approach can be noted:

a. Better application of the principle of conditionality, as well as the introduction of negative conditionality in the case of stagnation or backsliding of reforms. Thus, providing that " $\mathrm{t}] \mathrm{h}$ he core element of the merit-based accession process is its conditionality" and that "conditions must be clear from the outset", the accession process must be characterized by predictability, "[t]he Commission will better define the conditions set for candidates to progress, in particular through its annual reports. These conditions must be objective, precise, detailed, strict and verifiable"22. In this sense, on the one hand, a number of positive conditionalities are established (if countries move on reform priorities agreed in the

\footnotetext{
20 For a critical analysis, see Andreas Eisl, Les arguments contestables de la France contre l'élargissement de l'UE, Institut Jacques Delors - Europe dans le monde https://institutdelors.eu/publications/frances-questionnable-arguments-against-eu-enlargement/\#_edn1 (accessed 15 November 2021).

21 House of Lords, The future of EU enlargement, European Union Committee, 10th Report of Session 2012-13, pt. 59.

22 Ibidem, p. 5.
} 
negotiations sufficiently): accelerated integration and "phasing-in" to individual EU policies, the EU market and EU programmes' and increasing funding and investment "through a performance-based and reform-oriented Instrument for Pre-accession support and closer cooperation with IFIs to leverage support". On the other hand, a number of negative conditionalities are also taken into account, such as putting on hold negotiations in certain areas, suspending the entire negotiation (as it happened de facto in case of Turkey), reopening the already closed chapters, reducing the EU funding (except for that to civil society), pausing or withdrawing benefits of closer integration.

However, a number of questions remain about this system of conditionality. Thus, decisions on corrective action should be based on the annual assessment carried out by the Commission in its enlargement package on the overall balance in the accession negotiations. Member States should be able to contribute to this progress by signalling to the Commission any stagnation or serious backsliding in the reform process (this provision opens up the possibility of conflicting interpretations by different Member States to meet their purely domestic political needs, most often related to elections). Then, it is still unclear what this will look like in practice (among other things, how to achieve inclusion in EU policies, to what extent the new Multiannual Financial Framework can allocate more funds for preaccession aid, how Member States will use the instigates the application of corrective measures) and whether the right balance between positive and negative incentives will be realized, which is particularly problematic given that insisting on sanctions alone may not be particularly encouraging for the reforms.

b. Clustering of negotiation chapters (grouping 35 negotiation chapters into six thematic clusters). This represents "the most concrete, applicable and potentially beneficial element" of the new methodology ${ }^{23}$, offering a chance to accelerate the process, for example, with the opening of up to 9 chapters at once (under the condition that some secondary issues in less important chapters will not hold the entire negotiation cluster). The screening process would be carried out per cluster, while the "priorities for accelerated integration and key reforms will be agreed between the EU and the candidate country". Once these priorities successfully satisfied, the cluster would be 'opened without further conditions and closing benchmarks are set for each chapter'.

Under the new approach, even greater priority is given to fundamental political reforms such as the rule of law, the functioning of democratic institutions, fighting corruption - Chapters 23 (Judiciary and Fundamental Rights) and 24 (Justice, Freedom, and Security), issues that were already the subject of an early approach in the negotiations with Montenegro and Serbia. Thus, "negotiations on the fundamentals will be opened first and closed last and progress on these will determine the overall pace of negotiations" 24 . Also, interim benchmarks for Chapters 23 and 24 is a precondition for any advancement in all other clusters.

\footnotetext{
23 Uroš Ćemalović, "Towards a new strategy for EU enlargement- Between the wish for an encouragement, the reality of the fatigue and the threat of a dead end", EU and Comparative Law Issues and Challenges Series (ECLIC), Issue 4, 2020, p. 290.

${ }^{24} \operatorname{COM}(2020) 57$, pp. 2-3.
} 


\section{Concluding remarks}

The new methodology emphasizes fair conditionality of accession negotiation and incentives for candidate countries. However, doubts have already been expressed whether the new methodology was nothing but a face-saving trick ${ }^{25}$ and whether it is not at the same time a signal to the "recalcitrant" states within - that the system of values and foundations is strongly anchored in the Union's internal and external action, all the more so as some of these Member States are most in favor of enlargement (put additional pressure on Member States).

In fact, the doctrine has widely emphasized that "the ongoing processes in the EU suggest a convergence between the pre-accession and membership approaches to the rule of law; and could in turn foreshadow a more integrated approach towards rule of law"26.

Previous enlargements have shown that even the strongest emphasis given to foundations of political and legal systems in accession negotiations will not provide full protection against potential abuses of the rule of law and authoritarian drift in individual countries once they become EU members. However, the conditionalities related to enlargement, and especially those in the post-accession phase included in the CVM for Romania and Bulgaria, have contributed to the progressive articulation of a set of EU standards in the field of the rule of law (a holistic rule of law approach), including mechanisms to monitor compliance with the rule of law at Member State level (such as the European Commission-led Rule of Law Review Cycle) and even a new regime of negative conditionality for the protection of the EU budget (Regulation 2020/2092), which provides for sanctions in case of rule of law deficiencies. At the same time, the European Commission is increasingly referring to the jurisprudence of the CJEU in setting relevant standards on governance and judicial independence in accession talks with the countries of the Western Balkans.

In this context, the question arises whether the introduction of negative incentives for candidate countries (reduction of funds) is rather an additional argument to support the link between European funding and respect for democratic criteria, including (or especially) within the Union. Seen in this note, the new enlargement methodology seems to bring additional arguments in relation to Member States that do not adhere to the EU rule of law approach and even to maintain special post-accession monitoring of Romania and Bulgaria.

On the other hand, the question arises as to how realistic are the expectations of compliance with the standards of the rule of law, how predictable are these criteria for candidate countries, given the still evolving nature of this concept (especially through the jurisprudence of the CJEU)

Last but not least, although the new approach refers to "objective criteria" and "objective set conditions", if not followed by their common interpretation by all Member States, they would remain empty words, without any concrete implications. Or, on the sidelines of the EU-Western Balkans Summit in Brdo (6 Oct 2021), European Council President Charles

\footnotetext{
${ }^{25}$ CEPS - Centre for European Policy studies, $A$ credible new accession methodology or just a facesaving exercise?https://www.ceps.eu/a-credible-new-accession-methodology-or-just-a-face-savingexercise/ (accessed 15 November 2021).

${ }^{26}$ Ivan Damjanovski, Denis Preshova, Is the EU's Accession Conditionality Paving the Way for a More Integrated Rule of Law Policy in the EU?, EU IDEA Op-ed No. 5, March 2020, p. https://euidea.eu/2020/03/01/is-the-eus-accession-conditionality-paving-the-way-for-a-moreintegrated-rule-of-law-policy-in-the-eu/ (accessed 10 November 2021).
} 
Michel declared that there was a controversy between the countries of the European Union on the capacities of the latter to admit new members into the bloc.

Undoubtedly, institutional and national interests will continue to play an important role in the enlargement process, which downplays the effects of the new approach.

\section{Bibliography:}

1. Berkowitz, Peter, Catalina Rubianes, Ángel, Pienkowski, Jerzy, The European Union's experiences with policy conditionalities, EC-OECD Seminar Series on Designing better economic development policies for regions and cities, 2017, https://www.oecd.org/cfe/regionaldevelopment/Berkowitz_Conditionalities-for-MoreEffective-Public.pdf ;

2. Ćemalović, Uroš, "Towards a new strategy for EU enlargement-Between the wish for an encouragement, the reality of the fatigue and the threat of a dead end", EU and Comparative Law Issues and Challenges Series (ECLIC), Issue 4, 2020, pp. 281-298;

3. Damjanovski, Ivan, Preshova, Denis, Is the EU's Accession Conditionality Paving the Way for a More Integrated Rule of Law Policy in the EU?, EU IDEA Op-ed No. 5, March 2020, https://euidea.eu/2020/03/01/is-the-eus-accession-conditionality-paving-the-wayfor-a-more-integrated-rule-of-law-policy-in-the-eu/;

4. Eisl, Andreas, Les arguments contestables de la France contre l'élargissement de l'UE, Institut Jacques Delors - Europe dans le monde, https://institutdelors.eu/publications/frances-questionnable-arguments-against-euenlargement/\#_edn1;

5. Gateva, Eli, European Union Enlargement Conditionality, Palgrave Macmillan, 2016;

6. Grabbe, Heather, The EU's transformative power: Europeanization through conditionality in Central and Eastern Europe, Basingstoke, Palgrave, 2006;

7. Hillion, Christophe, "Enlargement of the European Union: The Discrepancy Between Accession Conditionality and Membership Obligations", in Fordham International Law Journal, Vol. 27, 2004, pp. 715-740;

8. Hillion, Christophe, The Creeping Nationalisation of the EU Enlargement Policy, Swedish Institute for European Policy Studies, Report 6/2010, https://sieps.se/en/publications/2010/the-creeping-nationalisation-of-the-eu-enlargementpolicy-20106/Sieps_2010_6.pdf;

9. Ker-Lindsay, James, Armakolas, Ioannis, Balfour, Rosa, Stratulat, Corina, The national politics of EU enlargement in the Western Balkans, Southeast European and Black Sea Studies, Vol. 17, No. 4, 2017, pp. 511-522;

10. Kochenov, Dimitry, EU Enlargement and the Failure of Conditionality. Pre-accession Conditionality in the Fields of Democracy and the Rule of Law, Kluwer Law International BV, The Netherlands, 2008;

11. Marcu, Ionuț-Mircea, Perspectiva parcursului european pentru statele din Balcanii de Vest. Intre „oboseala extinderii”, influențe externe și integrarea europeană, Institutul European din România, Working Paper Series No. 38, Aprilie 2021.

12. Mătușescu, Constanța, "Câteva considerații privind parcursul României în Uniunea Europeană la peste un deceniu de la aderare", în Ion M. Anghel (coord.), De la infăptuirea Marii Unirii la integrarea României în Uniunea European", Universul Juridic Publishing House, Bucharest, 2019, pp. 64-79. 
13. Mayrgündter, Tanja, The “Enlargement Paradox”: Intergovernmental Supranationalism Survives despite the Winds of Change, Les études du CERI, ${ }^{\circ} 211$, SciencesPo, 2015;

14. Schimmelfennig, Frank, "EU Enlargement and Differentiated Integration: Discrimination or Equal Treatment?”, in Journal of European Public Policy, Vol. 21, No. 5, 2014, pp. 681-698;

15. Vahlas, Alexis, "Appartenance a l'Union européenne", in Vlad Constantinesco \& al. (dir.), Le Traité établissant une Constitution pour l'Europe. Analyses et commentaires, Strasbourg, Presses universitaires de Strasbourg, 2005, pp. 239-278. 